Revista Iberoamericana, Vol. LXXI, Núm. 213, Octubre-Diciembre 2005, 1097-1107

\title{
EL COLÓN DE POSSE: ¿UN HÉROE ÉPICO?
}

POR

Romain Magras

Universidad de Lille III

A ejemplo de numerosos hombres que "hicieron la Historia”, Cristóbal Colón se ha visto sometido, como su expedición, a un sinfín de lecturas, en el campo de la historiografía o de la ficción, hasta convertirse en un verdadero "mito", despojado de su esencia humana y convertido en estatua de bronce. Puente entre el Medioevo y los tiempos modernos, entre dos continentes, inspiró en las últimas décadas a varios novelistas latinoamericanos que lo ficcionalizaron y lo hicieron protagonista de sus novelas: el cubano Alejo Carpentier publicó en 1979 El arpa y la sombra, poco antes de que apareciera Los perros del paraíso, del argentino Abel Posse, en 1983. Algunos años más tarde, en el contexto de la controvertida celebración del quinto centenario del llamado “descubrimiento”, el escritor paraguayo Augusto Roa Bastos publicó Vigilia del Almirante en 1992.

Alejo Carpentier había dejado claro, al salir a la venta su novela, que la concebía como una respuesta a las lecturas hagiográficas de los Papas Pío IX y León XIII, prolongadas después por Paul Claudel y Léon Bloy, quienes le atribuían al genovés virtudes sobrehumanas y una dimensión profética. Así pues, en este caso, la ficción pretendía brindar una lectura alternativa a la historiografía que la había precedido. Carpentier sustituyó a aquel heraldo de Dios, estatua desencarnada, por la imagen de un arribista megalómano que, después de mantener relaciones sexuales con la "muy católica Isabel de Castilla”, no vaciló, por afán de lucro, en instituir la esclavitud de los amerindios.

Nos proponemos aquí definir los principios que rigen la ficcionalización de Colón en Los perros del paraíso, en particular en relación a la tradición historiográfica y literaria: ¿en qué medida se integran en la ficción los textos y discursos historiográficos ? ¿Mediante qué procedimientos ? ¿A qué tratamiento los somete el texto ficcional ? Después de contestar estas preguntas, pondremos de manifiesto la recurrencia de rasgos morfológicos paradigmáticos de los "héroes épicos" que, si bien de buenas a primeras permitirían asimilar al Colón posseano con un "héroe épico”, son distorsionados para dotarlo de una dimensión resueltamente original.

La diégesis de Los perros del paraíso presenta a un Cristoforo Colombo a quien el lector verá evolucionar desde su infancia hasta su arresto, que corresponde, este último, al aciago desenlace del tercer viaje del personaje referencial. El relato, asumido por un narrador heterodiegético omnisciente que se identifica con el autor, se centra primero en el joven Cristoforo y en los futuros “Reyes Católicos” conjuntamente, para más adelante enfocar en el navegante que irá monopolizando el protagonismo. 
El Colón de Posse conserva muchos rasgos del personaje referencial, lo cual se logra mediante hechos, notaciones, y por la integración de elementos intertextuales a través de diversas modalidades como la cita textual, el comentario, la alusión o el pastiche. Si bien este procedimiento crea un parentesco entre el ser ficcional y el referente histórico, el autor no pretende reproducir la "estatua de bronce” de una figura ya intrínsecamente inestable, inasible. En efecto, el "referente” Colón todavía conserva una parte de misterio y ha sido el soporte de una multiplicidad de lecturas historiográficas a veces contradictorias: se pone en tela de juicio la fiabilidad de sus escasos documentos autógrafos ${ }^{1} \mathrm{y}$ muchas preguntas no tienen respuesta, como su fecha de nacimiento, sus posibles orígenes judíos, ${ }^{2}$ el móvil real de su casamiento con Felipa Muñiz Perestrello ${ }^{3}$ o los orígenes de Beatriz Enríquez, madre de su hijo Hernando. Otro punto que todavía divide a los estudiosos y que nos interesa sobremanera es la motivación del genovés: ¿quería encontrar estas tierras por codicia o, como lo deja pensar su descripción de la Boca del Dragón, ${ }^{4}$ por convicción religiosa ${ }^{5}{ }^{¿}$ Qué tipo de relaciones mantiene la obra de Posse con la historiografía?

\section{Los Perros del Paraíso y la historiografía}

En muchas ocasiones, el texto ficcional aparece como un palimpsesto en el que se traslucen sus genotextos: dado que la ficción condensa, unifica en un solo viaje los cuatro viajes del personaje referencial (175) y confunde su llegada a las Antillas con el descubrimiento de la Boca del Dragón (189), ${ }^{6}$ los intertextos integrados en la ficción proceden esencialmente de las relaciones de su primer y de su tercer viajes. Así, el relato hace un pastiche de la crónica de Colón del 13 de octubre de 1492, pues la reproduce fielmente, hasta que toma el relevo un fragmento puramente ficcional. ${ }^{7}$ Asimismo, la

${ }^{1}$ El Diario de a bordo es una copia que realizó Bartolomé de las Casas, y la biografía que escribió su hijo Hernando podría ser una mera copia de la versión lascasiana. Véase Cioranescu.

${ }^{2}$ Salvador de Madariaga fue quien defendió con más tesón esta tesis y, recientemente, el cazador de nazis Simon Wiesenthal, en Sails of hope: the secret mission of Christopher Colombus, la desarrolló al sostener que Colón quería irse a las Indias para llevar allá a sus correligionarios amenazados de expulsión. Se apoyó en una coincidencia: Colón salió de Sevilla el 3 de agosto de 1492, día señalado para la expulsión de los últimos judíos del reinado.

${ }^{3}$ Felipa Muñiz Perestrello, aristócrata portuguesa, era la hija del ex gobernador de Porto Santo. Dio a luz a su primer hijo, Diego, pero ciertos historiadores estiman que Colón se casó con ella para mejorar su conocimiento de la navegación. En esta isla fue donde Colón habría conocido al "piloto desconocido” y robado -según Madariaga- la famosa carta de Toscanelli, que revelaba la posición de tierras situadas al oeste.

${ }^{4}$ Durante su tercer viaje, al llegar a la Boca del Dragón, Colón parece seguro de haber alcanzado el Paraíso Terrenal (Varela 217-21).

${ }^{5}$ Todorov (14-54) admite la posible codicia de Colón (piensa más bien que hablaba de oro para satisfacer a sus socios) pero privilegia la dimensión evangélica de su empresa, que el propio Colón trató de subrayar. En efecto, el genovés parecía piadoso o al menos un asiduo lector de los textos sagrados, pues son numerosas las citas del Antiguo Testamento en su Diario de a bordo y en su Libro de las Profecías.

${ }^{6}$ El narrador dice que estos dos días se siguen en la vida del Almirante.

${ }^{7}$ Comparar la página 202 de Los perros del paraíso con Varela 31-2. 
ficción, cuando compara el Paraíso con una pera coronada por un pezón $(192,196)$, imita la descripción hecha por el genovés a los Reyes Católicos (Varela 217-8, 220 y 221) y al Papa Alejandro VI (286).

Sin embargo, las más de las veces los intertextos se ven sometidos a una distorsión que el narrador justifica por medio de un discurso metaficcional. En efecto, para él los documentos historiográficos no constituyen una referencia, primero porque los documentos autógrafos de Colón no son auténticos: “Después, en el pupitre [Colón] inauguró con su reconocida caligrafía el Diario Secreto que su hijo bastardo, Hernando, dañaría irremediablemente y del cual el padre Las Casas recogería algunas cenizas, sólo pasajes de sensatez” (141). Lamenta también las lagunas de la historiografía: "muy poco de lo importante queda por escrito, de aquí la falsedad esencial de los historiadores” (109).

La noción de "referente" es utópica: el referente es algo inalcanzable, porque cualquier discurso historiográfico es el resultado de una selección subjetiva y, por esta razón, no puede pretender la objetividad (Le Goff y Nora). La ficción resalta que la historiografía solo se interesó en los grandes acontecimientos: "Solo hay historia de lo grandilocuente, de lo visible, en actos que terminan en catedrales y desfiles...” (66), y por consiguiente en un ninguneo de la "intrahistoria” de la humanidad: "Resulta históricamente inexplicable la falta de decisión de Colón para quedarse en Gomera casándose con la viuda. No hay documentos. Los fracasos y los miedos no se confían a la posteridad” (159). La frontera entre la ficción y la historia, en tanto relato subjetivo, parcial y sesgado, se desdibuja, y es por esto por lo que el relato ficcional se va a insertar en las grietas del discurso historiográfico para corregirlo, complementarlo.

Así, la ficción colma el blanco que dejó el genovés en cuanto a su estadía en La Gomera: Las Casas resume en veinticinco líneas el período que va desde el 9 de agosto al 6 de septiembre de 1492 (Varela 18-9), sin profundizar en las ocupaciones de Colón. A partir de una frase ambigua de Michel de Cúneo, quien acompañó al genovés en su segundo viaje, la ficción desarrolla en más de quince páginas (145-61) y con múltiples detalles, el encuentro de Colón con la viuda del gobernador, "La Dama Sangrienta”, y su unión orgiástica. A través de un discurso metaficcional que parodia el del historiador, el narrador se interroga sobre el valor de los testimonios referentes a esta estadía e impone así implícitamente el suyo: "El relato del guardia a Morrison, aparte de haberse producido cincuenta años después de los hechos, está maleado por la insanable visión bidimensional de la sexualidad que padecía el joven gallego” (153).

Del mismo modo, el narrador-autor, en su discurso metaficcional, desacredita también, como si formara parte del corpus historiográfico, la lectura hecha por Carpentier, que supone que Colón fue el amante de la Reina Isabel.

Ante ella, la Reina, su carne se retrajo sin posibilidad de movimiento alguno. (Por eso yerra el gran Alejo Carpentier cuando supone una unión sexual, completa y libre, entre el navegante y la Soberana. La noble voluntad democratizadora lleva a Carpentier a ese excusable error. Pero es absolutamente irreal. La intimidación del plebeyo fue total en el aspecto físico. Total, en cambio, fue su descaro metafísico y así alcanzó la liberación del panorgasmo). (119-20) 
En un paréntesis, Posse, por supuesto en tono irónico, declara que, si bien queda claro que el escritor de ficción puede legítimamente rellenar los blancos dejados por la historia, debe hacerlo respetando cierta verosimilitud. Entonces, algo queda por definir: ¿quién es el Colón de Posse?

El Colón de Posse, ¿Un héroe éPICo?

En la novela de Posse, el protagonista pocas veces toma la palabra: así, el personaje se construye predominantemente gracias al discurso del narrador omnisciente; este discurso, al penetrar en la intimidad del personaje, le brinda al lector las "motivaciones reales” de Colón que tanto dividen a los historiadores. Pero la enunciación también parece cumplir otra función fundamental: dotar al personaje de los rasgos morfológicos del héroe épico.

¿Qué es un héroe épico? Hegel dividió a los héroes en tres categorías: el héroe épico, el héroe trágico y el héroe dramático. Nos vamos a interesar por la primera de estas categorías, cuyos representantes arquetípicos son Hércules y Aquiles. El héroe épico se define a través de ciertos rasgos y motivos: por ser un semidiós, es un mortal, muchas veces nacido en condiciones particulares que determinan su porvenir. Posee cualidades que lo sitúan por encima de lo humano, y supera con mucho a los seres que lo rodean. Amenazado al nacer por un entorno hostil, en un momento decide asumir, consciente y voluntariamente, su destino heroico. Su advenimiento como héroe, su epifanía, es un largo camino iniciático que recorre sorteando una serie de pruebas. Para eso, suele contar con la protección de los dioses. Su propósito es, por lo común, una causa justa a la que se dedica en cuerpo y alma, sin obedecer a ninguna regla moral, por eso es un ser asocial, caracterizado por su soledad. Por sus hazañas, suele deslumbrar a las mujeres y ser galardonado con sus favores. Después de su muerte, se convierte en objeto de culto (Sellier 14-22). ¿Qué es lo que enlaza al Colón de Posse con este paradigma?

En la ficción, el joven Cristoforo a priori nada tiene de un semidiós pues nace en el seno de una familia modesta. Sin embargo, algunas notaciones textuales le confieren, ya desde el comienzo de la obra, cualidades sobrehumanas: sus primos genoveses ven en él "la subversiva presencia del mutante, del poeta" (20). Jovencito, ya se comunica con los dioses tutelares del mar que, como lo atestigua la notación "el iniciado”, le transmiten un enigmático saber. Cristoforo también lleva una señal que augura su destino, es el "secreto" que esconde el protagonista a lo largo de la novela. El “secreto” del Colón referencial, al que el historiador Juan Manzano ha dedicado un valioso trabajo, remite a la posibilidad de que el genovés estuviera enterado de la existencia de tierras al Oeste, ya antes de su primer viaje. Sin embargo, en la ficción este “secreto" aparece tratado paródicamente: se refiere a una curiosidad anatómica que predestina a Colón para sus viajes transatlánticos: ¡el protagonista es un ser anfibio, palmípedo! ${ }^{8} Y$, a veces, la enunciación se apoya en esta curiosidad para proponer una lectura ficcional de ciertos acontecimientos documentados

8 "Va casi desnudo, los pies cubiertos -como siempre, para proteger su secreto- con las medias tejidas por la 'mamma'” (20). "Fue entonces cuando pudo enterarse del secreto que hasta entonces sólo conocía Susana Fontanarrosa y que Colón había ocultado siempre tras la densa malla de sus calcetines: entre el segundo y el tercer dedo de cada pie había una membrana unitiva, como la de los 
en la vida del personaje referencial: por ejemplo, explica por qué Colón salió ileso de su naufragio cerca de las costas portuguesas en $1476 .^{9}$

La construcción épica se lleva a cabo a través de la conexión implícita del protagonista con otras figuras heroicas, tales como Ulises, Eneas, Jasón, Moisés ${ }^{10}$ o Jesús. ${ }^{11}$ Por eso, de entrada, el joven Cristoforo aparece como el portador de una misión y de un destino descomunales.

¿En qué consiste esta misión? Al parecer, tiene un carácter religioso, pues la enunciación presenta repetidamente al protagonista como hijo del profeta Isaías, ${ }^{12}$ y las notaciones textuales que caracterizan al protagonista construyen una isotopía de la luz: “soñador”, “iluminado”, “alumbrado”, “sublimado”, o de la religión: “elegido”, "místico”.

Este rasgo ficcional se inspira en la historiografía: Colón, en su Libro de las Profecías, había interpretado algunos fragmentos del libro de Isaías ${ }^{13}$ como el vaticinio del descubrimiento de América y también se había presentado ante los Reyes Católicos como el "mensajero" de Isaías. ${ }^{14}$ En realidad, lo novedoso de la ficción de Posse radica en que esta "misión" será el prisma a través del cual todos los actos del protagonista van a buscar su coherencia.

Este destino heroico prometido al protagonista se fragua a través de unas pruebas, las “epifanías”, que consagran su advenimiento como héroe. La primera de ellas es el momento en que él asume consciente y voluntariamente su destino.

El universo que rodea al joven Cristoforo le manifiesta hostilidad: de buenas a primeras, desde su primera aparición, es perseguido y golpeado por sus primos sastres que quieren impedir que se rebele en contra de su destino ${ }^{15}$ de cardador. La enunciación, a través del discurso de su madre ${ }^{16}$ y del anacrónico lansquenete Ulrico Nietz, interpreta esta desventura como la primera prueba del largo camino iniciático que espera al protagonista: “Coraje, muchacho. Todo lo que no te mata te hará más fuerte” (24).

Un poco antes, el adolescente se rebela en contra de sus orígenes al robar el alfabeto de la parroquia de Génova. Este acto, reprensible de por sí, viene justificado por su misión:

patos y otros animales de ambiente acuático-terrestre. El Almirante era palmípedo y -ya no cabían dudas- preferentemente anfibio” (207).

9 “¡Tantos se habían ahogado! Él se impuso por su indeclinable fe en su misión y en la intuición de su naturaleza preferentemente anfibia (se quitó las medias a pesar de la marejada y llegado a la costa tuvo la suerte de encontrar en seguida con qué cubrirse los pies, su secreto)” (75).

${ }^{10}$ Éxodo, XIV, 21-22, 27-28 y 29.

${ }^{11}$ Evangelio de San Mateo, XIV, 22-33.

12 Ver 71, 109, 131, 165, 185, 205.

${ }^{13}$ Libro de Isaías, LI, 1-2; LVI, 19a y Cristóbal Colón. Libro de las profecías 58-74.

${ }^{14}$ Carta a los Reyes Católicos del 31/08/1498 (Varela, 205); carta escrita en 1500 y dirigida a Juana de la Torre (Ibid., 243); carta a los Reyes Católicos de 1501 (Ibid., 254-255).

${ }^{15}$ Fernando Aínsa: “(...) el origen de los mitos fundadores de la Civilización, son los hombres que no se han conformado con su destino y que han sido capaces de rebelarse contra el orden establecido, los únicos que pueden tipificarse como héroes” ( Sáinz de Medrano 70-1).

16 “[C]omprendía que el rito que sucedería era la imprescindible prueba que nace del odio y del resentimiento de los mediocres y que sirve para medir, fortalecer y templar la virtud de los grandes" (21). También: "Inútil que lo hagan. Es de la raza de los gigantes. Nada ni nadie podrá detenerlo" (22). 
es imprescindible que aprenda a leer para conocer los textos sagrados que describen la tierra que pretende alcanzar, el Paraíso. Pero el hurto se convierte en prueba pues recibe un castigo humillante (29). En la ficción, el interés del protagonista por los textos sagrados va a silenciar casi totalmente un eje privilegiado por los historiógrafos: las lecturas de los cosmógrafos, de las relaciones de viajes, los mitos que construyeron el imaginario colombino. En la novela, en ningún momento el protagonista pretende alcanzar Antilia, Cathay, Cipango u otras tierras míticas; la tierra que anhela es, no más ni menos, el Paraíso. De hecho, la novela parece desarrollar la aproximación mesiánica, milenarista al personaje histórico.

Para volver al paradigma, el protagonista de la ficción cumple un papel providencial: es esperado por los Reyes Católicos como la "sota rubia, de ojos verde-mar", ${ }^{17}$ y los agoreros aztecas también anuncian su venida. En realidad, Colón es en la novela el punto de convergencia de todas las esperanzas del mundo en el que vive: el Occidente está agonizando y espera su renacimiento: “Occidente, vieja Ave Fénix, juntaba leña de cinamomo para la hoguera de su último renacimiento. Necesitaba ángeles y superhombres. Nacía, con fuerza irresistible, la secta de los buscadores del Paraíso” (13); las multinacionales buscan nuevas salidas; ${ }^{18}$ los judíos a punto de ser expulsados necesitan una tierra de asilo. ${ }^{19}$

Aquí también, la relación entre ficción e historiografía es interesante: implícitamente, la novela integra las lecturas historiográficas que vieron a Colón como un ser codicioso o, a ejemplo de Wiesenthal, como el salvador de los judíos. A través de un fenómeno de inversión de perspectiva, esos móviles nunca habitan al personaje, obsesionado con su misión: los banqueros tienen intereses financieros, los judíos huyen de España gracias a su expedición, pero nada en la enunciación permite atribuirle al protagonista estos propósitos. ${ }^{20}$ Así, las lecturas de la historiografía más aceptadas están presentes en la ficción, pero ninguna de ellas se privilegia, ${ }^{21}$ dicho de otro modo, implícitamente, la ficción les resta validez.

Entre las pruebas que debe superar el héroe, también cabe citar su larga espera y la amenaza inquisitorial (73). Asimismo, la descripción de las vicisitudes de la travesía del

\footnotetext{
${ }^{17}$ Isabel a Fernando: “A propósito: ¿encontraste la sota rubia prevista por la bruja gitana? El caballero moreno ya apareció, no tengo dudas: se llama Gonzalo y es de Córdoba” (85); respuesta de Fernando a Isabel: “ ¿Has encontrado la sota de ojos verde-mar ? Me dicen que, en los juegos de barajas aragoneses, todas las sotas tienen ojos azulados. Pero hay que insistir: todo Imperio se basa en un almirante y un gran mariscal” (89); cuando la patrulla inquisitorial viene a la taberna a buscarle: "Buscamos a un rubio, de ojos azules, que podría ser marrano. ¡Orden del Rey! -Mostró una sota de un juego de baraja” (100).

18 “[L]as multinacionales se asfixiaban reducidas a un comercio entre burgos” (13).

19 "Hacía tiempo que hombres como Santángel, Coloma, el Marqués de Moya y otros poderosos conversos sabían que debían conseguir al aventurero capaz de llevar la judería a la Nueva Israel” (109). Esta representación de Colón se prolonga en su recurrente equiparación con Moisés (23, 71, 78).

${ }^{20}$ Véase página 130: en el largo mensaje que le envía, Santángel lo ve como el enviado de Dios, pero la reacción de Colón desacredita esta representación: “Colón no tuvo tiempo de desilusionarlo con sus dudas”.

${ }^{21}$ Acaso se pueda exceptuar la que propone Tzvetan Todorov en La conquête de l'Amérique. La question de l'autre. Dicho sea de paso, así se explica, sin duda, la transposición anacrónica de este intelectual en la ficción, bajo la forma de un lansquenete que le sirve de ayudante a Colón.
} 
océano tiene resonancias homéricas porque, si bien el héroe no se destaca por sus hazañas guerreras, como Hércules o Aquiles, la enunciación narra el acoplamiento de Colón con la Dama Sangrienta, en La Gomera, como una lidia sexual (145-161). En efecto, es patente la amplificación épica y explícita la analogía con Ulises y Circe (126). Esta aventura es una prueba cuyo desenlace determina el futuro de la expedición, pues la amante del navegante, cuyo nombre es evocador, suele, como la mantis religiosa, deshacerse de sus amantes. Después de las Canarias, el resto de la travesía es peligroso y remite a la de los argonautas pues los marineros afrontan un bestiario maravilloso: "Los atroces grifones. El Octopus. El Orcaferone. Ahora sí, ahora estaba enfrentado. Los abismos de la Mar ignota. Las furias del viento: reino de los demonios" (161). ${ }^{22}$

Sin embargo, conviene señalar que la ficción no idealiza al personaje. Los héroes épicos, a pesar de la ejemplaridad de sus proezas, no estaban exentos de defectos (piénsese, por ejemplo, en las cóleras de Aquiles). A veces, cometen actos violentos o hasta bárbaros, pero que vienen dictados por el cumplimiento de su misión y que, así, no pueden ser juzgados moralmente. La construcción épica ficcional contesta así a los planteos de ciertos historiadores que, en ocasiones, condenaron su figura. Sin embargo, el punto de vista peyorativo del historiador se ve sustituido en la ficción por la voz y el punto de vista del narrador que, al atenuarlos, legitiman actos reprensibles y de este modo manipulan, convencen al lector imponiéndole su código axiológico. ${ }^{23}$

En efecto, el protagonista de la ficción es poco escrupuloso -rasgo que le valió al personaje referencial unos detractores entre los historiadores-; así, cuando falsifica los datos de navegación, el narrador lo legitima resaltando la ineptitud de los congéneres de Colón: "Es imprescindible vendar los ojos de los caballos cuando se pretende enfrentarlos al fuego o a un toro salvaje” (167). Siguiendo el ejemplo de muchos héroes épicos, Colón trata a las mujeres con pocos miramientos: seduce a unas viudas de marineros para robarles unos mapas mientras duermen (71), se casa por interés con Felipa Moñiz Perestrello y después, cuando estima que ella compromete su misión y que le aburre, la abandona o la mata, ${ }^{24}$ como hace Lope de Aguirre con su esposa en Daimón:

Los historiadores no están de acuerdo si llegados a Lisboa él la mató (o la despenó, para mayor precisión idiomática) o si, con discepoliana generosidad, para evitarle el oprobio de seguir viviendo con quien la había colgado en el comedor, sobre el trinchante ya mencionado, la vendió a los moros traficantes de blancas que la habrían rematado al mejor postor en el mercado de Casablanca. (79-80)

La atenuación entre paréntesis “(la despenó, para mayor precisión idiomática)”, que se refiere a un acto detestable, pone de manifiesto la voluntad del narrador de manipular al lector. Un ejemplo similar es el de la enunciación del crudelísimo interrogatorio del "piloto desconocido": el narrador añade entre paréntesis "Pero se le moría en los brazos y no podía seguir interrogándolo en nombre de la ciencia” (71-2).

Otro rasgo definitorio del héroe es su soledad, y la del Colón ficcional se explica por varias razones. Colón es depositario de un secreto, de un saber que le confiere cierta

${ }^{22}$ Un poco más tarde, enfrentarán a las sirenas (183).

${ }^{23} \mathrm{El} \mathrm{mismo} \mathrm{procedimiento} \mathrm{se} \mathrm{observa} \mathrm{en} \mathrm{otra} \mathrm{novela} \mathrm{de} \mathrm{Posse,} \mathrm{Daimón.} \mathrm{Véase} \mathrm{Magras.}$

${ }^{24}$ Analogía evidente con Eneas abandonando a Dido. 
superioridad respecto a sus hombres; por eso es repetidamente el sujeto de verbos como 'saber' y ‘comprender'. Además, como jefe de la expedición, es normal que ocupe un papel fuera del resto del grupo, que experimenta para con él un sentimiento ambiguo, entre el desprecio y la admiración (173, véase también 190).

Como héroe, el Colón ficcional asume un papel fundacional, es el creador de un universo. En efecto, lleva a sus hombres a una tierra maravillosa, ideal, el Paraíso. A continuación, como un Demiurgo, cumple un papel cosmogónico al recuperar el tiempo primordial y al instituir las reglas que van a regir este mundo. Por una inversión de perspectiva del Génesis, anula las leyes que Dios les impuso a los hombres postadánicos: en adelante, los hombres no trabajarán ("el estar”) y ya no tendrán que andar vestidos ("la desnudez"). ${ }^{25}$ Lógicamente, ocupa el centro de este espacio, el axis mundi, ${ }^{26}$ pues se instala al pie del Árbol de la Vida.

Por fin, cumpliendo con los cánones del género, el relato se acaba con la caída del héroe. Así se explica el hecho de que la diégesis no se interese en los últimos años de la vida del genovés: no le quedaría ninguna heroicidad a un almirante venido a menos. El héroe épico, al ser un semidiós, no puede acceder a la inmortalidad. Además, su caída suele vincularse a un error. En la enunciación, ¿qué es lo que justifica tal caída? Una cosa evidente es que, al recuperar el tiempo primordial y anular el tiempo lineal, el Almirante habría alcanzado la inmortalidad y como mortal estaba pues condenado a esta caída. Además, el protagonista de la ficción se inspira suficientemente en el personaje referencial como para que el lector no acepte un desenlace paradisíaco. El autor se ha propuesto rellenar blancos dejados por la historia, pero no reescribirla. ${ }^{27}$

Por la recurrencia de estos rasgos morfológicos, queda claro que Posse ha querido jugar con este concepto de héroe épico, pero no pensamos que haya querido imponerlo como tal. En efecto, el héroe, a pesar de tener algunos defectos, debe tener grandeza y ser reconocido. La amplificación en la enunciación lleva a veces a la caricatura: la erotomanía del Colón ficcional raya en lo grotesco pues ciertas notaciones lo equiparan con un animal; ${ }^{28}$ en otras ocasiones, está ridiculizado, como cuando se sumerge en un carro lleno de jalea para llamarles la atención a los Reyes Católicos (98), o cuando se acomoda en una hamaca que le sirve de trono.

${ }^{25}$ Por supuesto, aquí, Posse, por irrisión, convierte en un acto serio, sagrado y fundacional, los desmanes que cometieron por aburrimiento los blancos al llegar a estas nuevas tierras.

26 “Le Centre est donc la zone du sacré par excellence, celle de la réalité absolue. Pareillement, tous les autres symboles de la réalité absolue (arbres de vie et de l’immortalité...) se trouvent eux-aussi en un Centre. La route menant au centre est une 'route difficile' [...] et cela se vérifie à tous les niveaux du réel [...]; le chemin est ardu, semé de périls, parce qu’il est, en fait, un rite de passage du profane au sacré [...], de l’homme à la divinité.” (Eliade 30-1).

${ }^{27}$ Interrogado sobre lo que debía presidir la ficcionalización de los personajes históricos, Abel Posse se valió de una declaración de Marguerite Yourcenar referente a sus Mémoires d'Hadrien: "Ya sabemos que reconstruir el monumento es siempre tendencioso y siempre lo vamos a hacer a nuestra manera, pero lo importante es que todos los ladrillos sean verdad: eso es suficiente”. (Sáinz de Medrano 112).

28 “movido por una sana animalidad” (con Beatriz, 107), “el deseo salvaje que lo acometía” (con Isabel, 118); “entonces multiplicó al máximo su agresividad fálica” (con la Dama Sangrienta, 155). Igualmente, el narrador omnisciente nos brinda las zozobras que le asaltan y que le alejan de la figura 
Asimismo, el motivo que invalida al Colón posseano como "héroe épico" es su relación con el otro. Como lo dijimos, Colón casi nunca habla, no mantiene ninguna relación con nadie como si, del mismo modo que el superhombre nietzscheano, no necesitara a nadie. Sí dialoga, sin embargo, con los miembros de la "secta de los buscadores del Paraíso" y los "lansquenetes". Estos personajes son la transposición anacrónica de Nietzsche (Ulrico Nietz, síntesis de Friedrich Nietzsche y de Ulrico Schmidl), Marx (Mordecaï), Swedenborg y Borges (el ciego Osberg de Ocampo, "siempre ausente de la realidad de los otros" (205)). El protagonista mantiene relaciones con ellos, pero no se comunica realmente: son como unos alter ego de Colón, tienen certidumbres y cada cual es el único depositario de un saber en el que cree a pies juntillas. En realidad, todos son unos utópicos, pues Colón se cree el guía que lleva al hombre al Paraíso, Swedenborg dice haber visto unos ángeles; por su lado, Nietz y Mordecai son portadores de una cosmogonía del porvenir, pues el primero proclama la muerte de Dios (224-6), el eterno retorno de lo mismo, y el segundo el fin de la historia con el fin de la lucha de clases. La presencia anacrónica de estos seres en la expedición de Colón le da una dimensión trans-histórica a nuestro protagonista, tanto más cuanto que en su travesía del océano (como la expedición de Lope de Aguirre en Daimón), Colón se cruza con otros utópicos del futuro: los Pilgrim Brothers del Mayflower, Bolívar en su barco, y los barcos cargados de emigrantes italianos que van rumbo a la Argentina.

En Los perros del paraíso la heroicidad de Colón consiste en haberse rebelado en contra de su destino, aunque fuera algo vano. Más que el propio Colón histórico, fue el soñador, el rebelde, el "superhombre”, como lo llaman varias veces en el relato, el que interesó más a Abel Posse. El propósito de Posse no fue desmitificar o enaltecer la figura, sino más bien rescatar y valorar sus sueños de un futuro ideal. El contexto de producción de la obra puede verse como una clave de lectura. Lo simbólico de este viaje ficcional recuerda a otra novela de Posse, Daimón, publicada como LP durante el Proceso argentino. El Colón de Posse, de manera anacrónica y grotesca, habla como un argentino. ${ }^{29}$ Aunque Posse justificó esta ocurrencia por la ambigüedad de los orígenes de Colón, ${ }^{30}$

de un héroe: “¡Abandonar todo ! Huir con Beatriz y el niño y empezar en el mayor anonimato la delicia de una vida sin grandeza. Poner una farmacia en Flandes o una charcutería en Porto. ¡Huir de la historia ! [...] ¡Qué alivio ! Poder traicionarlos, abandonarlos pocas horas antes de zarpar” (132).

${ }^{29}$ El narrador justifica esta aserción valiéndose de un texto apócrifo: “Colón, como la mayoría de los argentinos, era un italiano que había aprendido español. Su idioma era necesariamente bastardo, desosado, agradablón y aclaratorio como el que abunda en la literatura del Río de la Plata. Colón decía piba, bacán, mishiadura, susheta. (Véase: Nahum Bromberg, Semiología y Estructuralismo, cap. IV: “El idioma de Cristoforo Colon”, Manila, 1974) (65).

30 "Yo jugué con Colón y, en cierta medida, Colón me pareció que era argentino. Porque él no era español, ni era absolutamente judío, como dicen, o por lo menos él, de religión, se declaraba católico. Era un personaje intermedio. Era el hombre que llega a América y que trae todas las contradicciones de ese continente, pero, al mismo tiempo, como era un marginal, podía adaptarse también a la comprensión de América, podía interpretar y tener una cierta flexibilidad mayor que los otros frente al indígena. [...] Entonces, al ser personaje puente entre las dos culturas, me pareció que también tenía algún elemento argentino, porque los argentinos son el puente entre los europeos y los americanos, participan de las dos” (Spiller 109-10). 
podemos preguntarnos si este Colón actualizado, este rebelde, este utópico, este héroe humano no será, al igual que los perros que le rodean en el paraíso, en la mente de Posse, el argentino contemporáneo del proceso a quien le toca, como a muchos otros héroes posseanos, ${ }^{31}$ rebelarse en contra de su presente para construir otro futuro.

Otra clave de interpretación de esta heroificación original del personaje histórico por la ficción puede intuirse en la función atribuida por Posse a $L P$ y a su protagonista en su declarado proyecto de "Trilogía del Descubrimiento":32 como ya lo señalamos, Daimón (1978) heroifica al antihéroe Lope de Aguirre mediante procedimientos observables en $L P$ (transgresión, inversión de perspectiva, parodia, intertextualidad y anacronismo), para convertirlo en la emblemática figura del héroe que se rebela -eternamente y en vanocontra la aciaga historia de su continente. El desenlace de Daimón confunde a su protagonista con Ernesto Che Guevara antes de su desaparición. Así pues, en el marco de esta trilogía y a pesar de su publicación posterior a la de Daimón-1981-, Los perros del paraíso parece tener el propósito de encumbrar al Colón histórico para convertirlo en la figura del héroe americano por antonomasia, por su papel de inventor, de fundador de un continente. Lope de Aguirre representaría, por su parte, la figura del conquistador guerrero, de libertador frustrado del Continente, mientras que el Cabeza de Vaca (figura invertida de la del guerrero) de El largo atardecer del caminante ${ }^{33}$ (1992) encarnaría la del conquistador espiritual fallido. En estas tres obras, los procedimientos de heroificación del personaje histórico evidencian tantas semejanzas que fundan sin duda un verdadero modelo del héroe posseano, que siempre viene dotado de una dimensión resueltamente americana y transhistórica, y que siempre sale derrotado. La elección por parte del

\footnotetext{
31 "Estos son los tipos de personajes que le interesan a Posse, los que él extrae de la historia, y lo hace de la misma forma en que vivieron sus héroes: desafiando el orden establecido. [...] A estos héroes, a estos superhombres, Abel Posse los extrae de su contexto histórico para introducirlos en un espacio temporal en el que esa constante del héroe se repite y se reencarna continuamente con distintas formas. [...] Es decir que hay toda una reencarnación, una reescritura constante del héroe mítico, y es en esa reescritura de los héroes míticos donde se inscribe la narrativa de Posse: los héroes son siempre los mismos, y son diferentes: los héroes son de ayer, de hoy y para siempre”. Fernando Aínsa en Sáinz de Medrano 70-1.

32 “Mis novelas son lo que llamo la 'Trilogía del Descubrimiento', y está compuesta por Los perros del paraíso -que es el episodio que nace en España y se fue a la América del Descubrimiento y del cual era puente Colón-, por Daimón -que fue publicada antes, pero sería la segunda porque es la vida del conquistador-, y por Los heraldos negros -que sería la tercera parte de la trilogía y ya tengo la mitad del libro escrito. [...] Los heraldos negros sería la tercera etapa, la del choque del judeocristianismo y las cosmovisiones americanas. Así como toda la otra etapa es la física del imperio que se impone sobre el otro, y la guerra, ésta es la física del dominio y la alienación cultural. En esas tres novelas, entonces, trato de visualizar cómo ha sido el proceso de nuestra dominación, la integración que se produce, el mestizaje de razas, la nueva etnia, que yo digo surge de la masiva violación”. ("La libertad...” 33-34).

${ }^{33}$ Esta novela muy posterior parece ahora marcar un hito: si siguen recurrentes el anacronismo, la parodia o lo carnavalesco, con la aventura de Cabeza de Vaca se abren paso en la poética de Posse nuevas modalidades en la reelaboración ficcional del personaje histórico: el monólogo interior, la introspección y la metaliteratura, por la introducción en el relato del personaje del autor como investigador, recopilador de testimonios.
} 
novelista de dos figuras más próximas pero inequívocamente míticas de la historia latinoamericana para protagonizar dos de sus novelas recientes -Eva Perón (La pasión según Eva, 1994) y Ernesto Che Guevara (Los cuadernos de Praga, 1998)-corrobora esta hipótesis: aunque con las décadas cambian los procedimientos empleados por Posse para heroificar a sus personajes de ficción inspirados en personajes históricos, todo apunta a que una de las mayores preocupaciones de su proyecto novelístico es elaborar a través de sus múltiples facetas la figura del héroe al que espera todavía el continente latinoamericano.

\section{BiBLIOgRafía}

Bauzá, Hugo Francisco. El mito del héroe. Morfología y semántica de la figura heroica. Buenos Aires: FCE, 1998.

Carpentier, Alejo. El arpa y la sombra. México: Siglo XXI, 1979.

Cioranescu, Alexandre. Colón y Canarias. Santa Cruz de Tenerife: Aula de Cultura de Tenerife, 1959.

Colón, Cristóbal. Libro de las profecías. Sevilla: Alianza, 1992.

Eliade, Mircea. Le mythe de l'éternel retour. Paris: Gallimard, 1969.

Le Goff, Jacques y Pierre Nora. Faire de l'Histoire. Paris: Gallimard, 1974.

Magras, Romain. "El Lope de Aguirre de Daimón: Abel Posse y la construcción del héroe”. Ponencia presentada en las V Jornadas Andinas de Literatura Latinoamericana, Santiago de Chile, 6-10 de agosto de 2001. Actas en prensa.

Manzano Manzano, Juan. Colón y su secreto. El predescubrimiento. Madrid: Cultura Hispánica, 1982.

Posse, Abel. Los cuadernos de Praga. Buenos Aires: Atlántida, 1998. La pasión según Eva. Buenos Aires: Emecé, 1994. Los perros del paraíso. [1983]. Buenos Aires: Emecé, 1994. El largo atardecer del caminante. Buenos Aires: Emecé, 1992. Daimón. [1978]. Buenos Aires: Emecé, 1989.

“La libertad no es un delirio literario”. Papeles para el diálogo 1 (Caracas, 1988): 30-7, 33-4.

Roa Bastos, Augusto. Vigilia del almirante. Madrid: Alfaguara, 1992.

Sáinz de Medrano, Luis, coord. Semana de autor. Abel Posse. Madrid: Cultura Hispánica, 1997.

La Santa Biblia. Madrid: San Pablo, 1989.

Sellier, Philippe. Le mythe du héros. Paris: Bordas, 1970.

Spiller, Roland. “Conversación con Abel Posse”. Iberoamericana Lateinamerika Spanien. Frankfurt am Main: Vervuert, 1989. 106-14.

Todorov, Tzvetan. La conquête de l'Amérique. La question de l'autre. Paris: Seuil, 1982. Varela, Consuelo. Cristóbal Colón. Textos y documentos completos. Madrid: Alianza, 1997.

Wiesenthal, Simon. Sails of Hope: The Secret Mission of Christopher Colombus. New York: Mc Millan Publishing, 1973. 